\title{
Aurélie Barre, "Renart et la mésange" dans le ms. O. La faim (fin?) de chair et de mots
}

\section{Maria Colombo Timelli}

\section{(2) OpenEdition}

1 Journals

\section{Édition électronique}

URL : http://journals.openedition.org/studifrancesi/9428

DOI : 10.4000/studifrancesi.9428

ISSN : 2421-5856

Éditeur

Rosenberg \& Sellier

\section{Édition imprimée}

Date de publication : 1 décembre 2007

Pagination : 627

ISSN : 0039-2944

\section{Référence électronique}

Maria Colombo Timelli, " Aurélie Barre, "Renart et la mésange" dans le ms. O. La faim (fin?) de chair et de mots », Studi Francesi [En ligne], 153 (LI | III) | 2007, mis en ligne le 30 novembre 2015, consulté le 08 janvier 2021. URL : http://journals.openedition.org/studifrancesi/9428 ; DOI : https://doi.org/10.4000/ studifrancesi.9428

Ce document a été généré automatiquement le 8 janvier 2021.

\section{(c)}

Studi Francesi è distribuita con Licenza Creative Commons Attribuzione - Non commerciale - Non opere derivate 4.0 Internazionale. 


\title{
Aurélie Barre, "Renart et la mésange" dans le ms. O. La faim (fin?) de chair et de mots
}

\author{
Maria Colombo Timelli
}

\section{RÉFÉRENCE}

AURÉLIE BARRE, 'Renart et la mésange” dans le ms. O. La faim (fin?) de chair et de mots, «Le Moyen Âge», CXII, 2, 2006, pp. 283-305.

Il s'agit de l'épisode central de la première unité de la branche II, consacrée à Renart et Chantecler. Le copiste du ms. $O$ modifie la branche tout entière et retravaille en particulier la rencontre de Renart et de la mésange en amplifiant la première partie (une trentaine de vers ajoutés) et en abrégeant la seconde. A.B. propose une interprétation de ce passage fondée sur le rapport qui s'instaure à ses yeux entre la faim de Renart et les mots dont il est contraint de se nourrir; de fait, l'auteur du ms. $O$ «gonfle [la branche II] de mots et d'images, [et] l'allège de ses actions» (p. 285). L'édition de l'épisode (vv. 410-621) est donnée en annexe aux pp. 300-305. 